\title{
Propofol effects on the morphology of rat testes subjected to testicular ischemia- reperfusion ${ }^{1}$
}

\author{
Efeitos do propofol sobre a morfologia do testículo do rato submetido à isquemia-reperfusão \\ testicular
}

\begin{abstract}
Antônio Urt Filho ${ }^{\mathrm{I}}$, Celso Massaschi Inouye ${ }^{\mathrm{II}}$, José Carlos Dorsa Vieira Pontes ${ }^{\mathrm{III}}$, Andréia Conceição Brochado Antoniolli Silva ${ }^{\mathrm{IV}}$, Guilherme Viotto Rodrigues da Silvav, Carlos Henrique Marques dos Santos ${ }^{\mathrm{VI}}$
\end{abstract}

${ }^{\mathrm{I}} \mathrm{MD}$, Assistant Professor, Surgery Department, UFMS, Mato Grosso do Sul, Brazil. Surgical procedure, samples colleting and acquisition and interpretation of data, statistical analysis, manuscript writing.

IIPhD, Associate Professor, Surgery Department, UFMS, Mato Grosso do Sul, Brazil. Critical revision.

${ }^{\text {III }} \mathrm{PhD}$, Associate Professor, Surgery Department, UFMS, Mato Grosso do Sul, Brazil. Design of the study, manuscript writing.

${ }^{\text {Iv }} \mathrm{PhD}$, Associate Professor, Surgery Department, UFMS, Mato Grosso do Sul, Brazil. Design of the study, statistical analysis.

${ }^{v}$ MD, Resident, Cardiovascular Surgery, UFMS, Mato Grosso do Sul, Brazil. Helped with technical procedures.

${ }^{\mathrm{V}} \mathrm{PhD}$, Associate Professor, Surgery Department, UFMS, Mato Grosso do Sul, Brazil. Interpretation of data and critical revision.

\begin{abstract}
PURPOSE: To evaluate the effects of propofol as an inhibitor of tissue injury in testicular ischemia-reperfusion in rats.

METHODS: 30 Wistar rats were assigned to one of three groups of 10 animals: G1, testicular exposure alone; G2 and G3: testicular ischemia caused by left spermatic cord torsion of $720^{\circ}$. In G3, propofol was administered intraperitoneally at $20 \mathrm{mg} / \mathrm{kg} / \mathrm{h} 45 \mathrm{minutes}$ after spermatic cord torsion. In G2 and G3, spermatic cords were detorsioned after $60 \mathrm{~min}$. In all three groups, testes were subsequently repositioned in the scrotum. After 90 days, bilateral orchiectomy was performed for histological examination.

RESULTS: No abnormalities in seminiferous tubules were found in G1. In G2, 86.6\% of left testes exhibited abnormalities, in contrast with $67.8 \%$ for right testes. In G3, these proportions were $57.3 \%$ and $45.6 \%$, respectively. A statistically significant difference was found between G2 and G3. CONCLUSION: Propofol reduced the tissue damage in rat testes subjected to ischemia-reperfusion caused by spermatic cord torsion.
\end{abstract}

Key words: Propofol. Testis. Ischemia. Reperfusion. Rats.

\section{RESUMO}

OBJETIVO: Avaliar os efeitos do propofol como inibidor da lesão tecidual na isquemia-reperfusão testicular em ratos.

MÉTODOS: Trinta ratos Wistar foram distribuídos em três grupos de 10 animais. G1: apenas exposição testicular. G2 e G3: isquemia testicular por torção do cordão espermático esquerdo a $720^{\circ}$. G3, 45 minutos após a torção do cordão espermático foi administrado propofol 20mg/Kg/hora via intraperitoneal. Após 60 minutos, nos grupos 2 e 3 foram desfeitas as torções dos cordões espermáticos e em seguida os testículos dos animais dos três grupos foram reposicionados no escroto. Após 90 dias foi realizada a orquiectomia bilateral para análise histológica.

RESULTADOS: Nos túbulos seminíferos do grupo 1 não se encontrou anormalidades. Nos túbulos seminíferos do Grupo 2, as anormalidades foram 86,6\% nos testículos esquerdos e 67,8\% nos testículos direitos. Houve diferença estatisticamente significativa quando se compararam os testículos dos grupos 2 e 3.

CONCLUSÃO: O propofol minimiza a lesão tecidual em testículos de ratos submetidos à isquemia-reperfusão na torção do cordão espermático.

Descritores: Propofol. Testículos. Isquemia. Reperfusão. Ratos. 


\section{Introduction}

Spermatic cord torsion is a frequent clinical event in emergency care services. It affects children, adolescents, and young adults, prompting emergency surgery because of its potential risk for orchiectomy and infertility, the latter caused primarily by ischemia-reperfusion. Duration and degree of spermatic cord torsion are the foremost factors determining testicular damage ${ }^{1,2}$.

The pathophysiology of spermatic cord torsion initially includes venous occlusion that leads to edema, which in turn causes arterial occlusion and consequent testicular ischemia ${ }^{3-5}$. Ischemia triggers an oxidative mechanism that increases production of reactive oxygen species. This event promotes, among other changes, damage to the cytoskeleton and cell membrane, with dysfunction of calcium pumps, activation of oxidizing enzymes, and mitochondrial changes that further limit the supply of adenosine triphosphate to cells ${ }^{6}$.

Reperfusion occurs subsequent to a period of cellular hypoxia, with increased production and consequent accumulation of purine metabolites - xanthines and hypoxanthines. Hypoxanthine is converted into xanthine, which in turn is transformed into uric acid, generating toxic by-products such as urates, superoxide radicals, and ultimately hydroxyl radicals ${ }^{6}$.

The association of these aggressive components—oxygen free radicals, chemotactic agents and leukocyte aggregation agents-induces lipid peroxidation, with membrane lysis, loss of endothelial integrity, and increased vascular permeability, resulting in tissue damage and cell death. To minimize this tissue damage (which is sometimes reversible), free radicals already formed have to be eliminated and, if possible, prevented from being generated ${ }^{6,7}$.

A number of substances have been investigated for their ability to protect tissues from ischemia-reperfusion effects, including antioxidants such as allopurinol, N-acetylcysteine (NAC), verapamil, vitamins C and E, diltiazem, and propofol.

Since its introduction in the 1980s, propofol (2,6-diisopropylphenol) has been gaining wider acceptance for induction and maintenance of anesthesia and sedation, producing minimal side effects and prompt anesthetic induction. Its chemical structure is similar to that found in the active moieties of endogenous antioxidants such as tocopherol and butylhydroxytoluene. These molecules adhere to cell membranes or to phospholipids to form free radicals, inhibiting lipid peroxidation by reacting with lipid peroxyl radicals to form phenoxyl, a non-reactive radical. Propofol might act through a similar mechanism. Its antioxidant effects are thought to result from inhibition of lipid peroxidation by formation of relatively unreactive free radicals capable of breaking the production chain of radicals that are potentially damaging to cell membranes ${ }^{8}$.

The purpose of this study was to conduct a histological evaluation of the effect of propofol on testicular ischemiareperfusion in rats.

\section{Methods}

The project was evaluated and approved by the Ethics Committee of the Federal University of Mato Grosso do Sul (UFMS) (permit 226/2009).

Thirty adult male Wistar rats (mean weight: 300g) from the UFMS laboratory animal facilities were used in the experiments. They were given water and chow ad libitum and were randomly assigned to one of three groups of 10 animals, as follows: G1: controls; G2: ischemia-reperfusion; G3: ischemiareperfusion + propofol.

Anesthesia was induced by intramuscular administration of ketamine at $5 \mathrm{mg}$ per kilogram of body weight plus xylazine at 2mg per kilogram.

Once anesthesia was achieved, the animals were kept in a supine position and underwent antisepsis of the scrotal region with 2\% iodine alcohol.

Using instruments for minor surgical procedures, a longitudinal incision of approximately $2.0 \mathrm{~cm}$ was made to the scrotal raphe, and tissue planes opened to expose the left testis.

G1 (controls): The left testis was exteriorized, immersed in $0.9 \%$ isotonic saline solution for $1 \mathrm{~h}$ at controlled room temperature, and repositioned in the scrotum. The incision was sutured with catgut 3.0 in continuous stitching on a single plane.

G2 (ischemia-reperfusion): The left testis was exteriorized and its spermatic cord torsioned $720^{\circ}$. The testis was then immersed in $0.9 \%$ isotonic saline solution for $1 \mathrm{~h}$ at controlled room temperature (Figure 1), after which the spermatic cord underwent detorsion and the testis was repositioned in the scrotum. The incision was sutured with catgut 3.0 in continuous stitching on a single plane. 


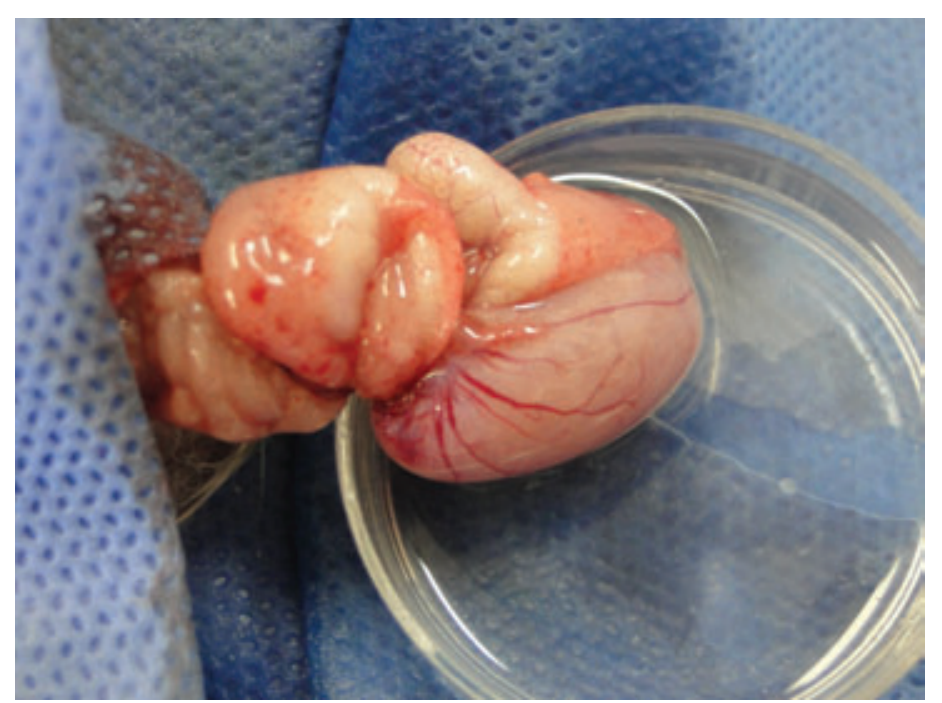

FIGURE 1 - Torsion of spermatic cord to $720^{\circ}$ in groups 2 and 3.

G3 (ischemia-reperfusion + propofol): The left testis was exteriorized and its spermatic cord was torsioned $720^{\circ}$. The testis was immersed in $0.9 \%$ isotonic saline solution at controlled room temperature for $1 \mathrm{~h}$ until detorsion. Fifteen minutes before detorsion, propofol was administered intraperitoneally at $20 \mathrm{mg} /$ $\mathrm{kg} / \mathrm{h}$.

At the end of the $1 \mathrm{~h}$ period the testis was repositioned in the scrotum and the incision was sutured using catgut 3.0 in continuous stitching on a single plane.

After the intervention, the animals were housed in cages and were given oral analgesic (dipyrone) at $15 \mathrm{mg} / \mathrm{kg}$ every $6 \mathrm{~h}$ for the first $24 \mathrm{~h}$.

The animals were followed up until day 90 post-surgery, at which point bilateral orchiectomy was performed (Figure 2).

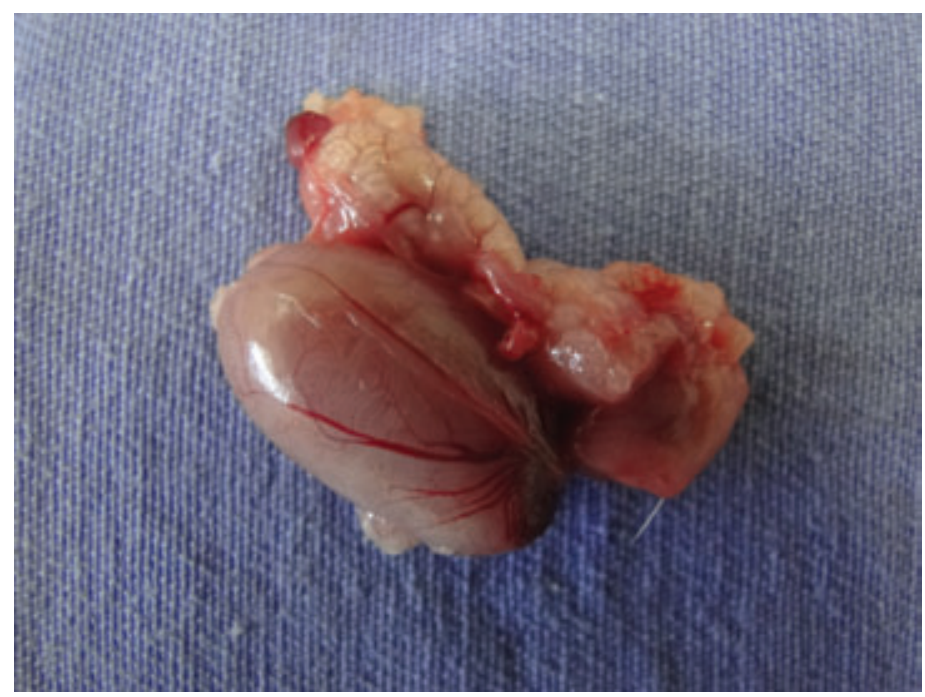

FIGURE 2 - Testis and spermatic cord after orchiectomy.

All animals were again anesthetized with ketamine plus xylazine and a longitudinal incision of approximately $2.0 \mathrm{~cm}$ was made to the scrotal raphe for removal of both testes - a procedure involving cord clamping and hemostasis.

The animals were then euthanized through cardiorespiratory arrest induced by an overdose of ketamine.

The right and left testes were identified, immersed in Bouin's fluid for 30min, and sent to the UFMS Laboratory of Pathology, where they were kept in a $10 \%$ formalin solution for 24h, and embedded in paraffin. Cross-sections $6 \mu \mathrm{m}$ thick were cut using a microtome.

The sections were subjected to hematoxylin-eosin staining and observed under an optical microscope. Histological variables (Table 1 ) were evaluated according to Cosentino et al. ${ }^{9}$.

TABLE 1 - Histological variables evaluated (according to Cosentino et al. ${ }^{9}$ ).

\begin{tabular}{ll}
\hline Seminiferous tubules & \\
& Loss of sperm cells and spermatids \\
& Absence of germ cell layers \\
& Degeneration of germ cell layers \\
& Structural damage to germ cells \\
Tubule rupture & \\
& Reactions in Leydig cells in ruptured tubules \\
Interstitium & \\
& Proliferation of Leydig cells \\
& Edema \\
& Hemorrhage \\
& Granuloma \\
& Fibrosis \\
\hline
\end{tabular}

Each testis was graded from 0 to 4 for each variable, with higher grades indicating greater tissue damage in the cross-section examined.

The histological evaluation sought to identify changes in the seminiferous tubules by detecting signs of necrosis and structural damage in the germinal epithelium, as follows:

Grade 0: intact seminiferous tubules

Grade 1: necrosis in superficial cells

Grade 2: necrosis in superficial and deep cells, with structural damage

Grade 3: distal necrosis in germ cells

Grade 4: disappearance of tubular structures

Student's $t$-test $(p<0.05)$ was applied for statistical analysis. 


\section{Results}

Figures 3-7 depict the histological patterns found for germ cells.

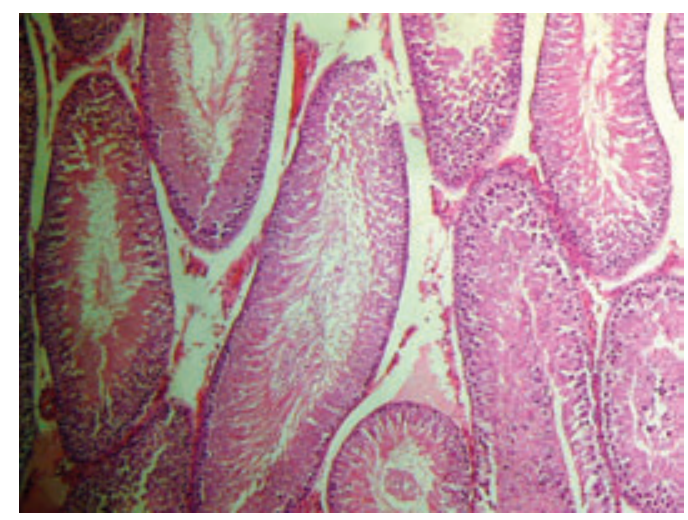

FIGURE 3 - Photomicrograph of normal seminiferous tubules (G1: controls). Right testis, 100×. Note sperm cell flagella filling the tubules. Germinal epithelium cells are well organized.

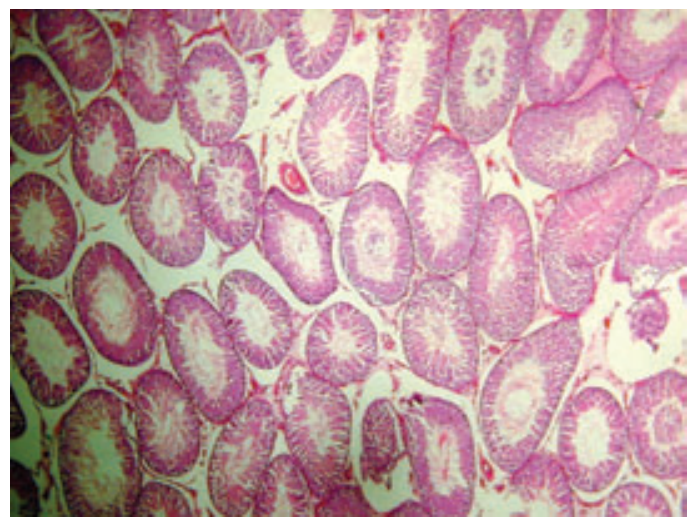

FIGURE 4 - Photomicrograph of normal seminiferous tubules (G1: controls). Left testis, 40×. Germinal epithelium cells are well organized.

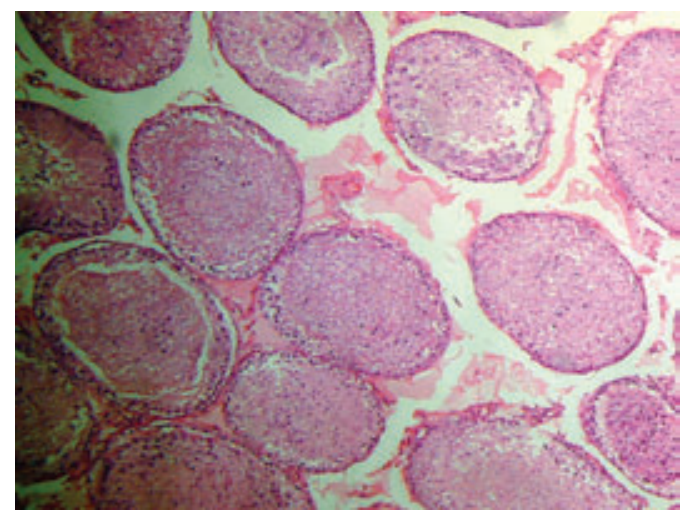

FIGURE 5 - Photomicrograph of altered seminiferous tubules (G2: ischemia-reperfusion). Left testis, $100 \times$. No viable cells are present. Seminiferous tubule lumen is filled with amorphous material containing cellular debris.

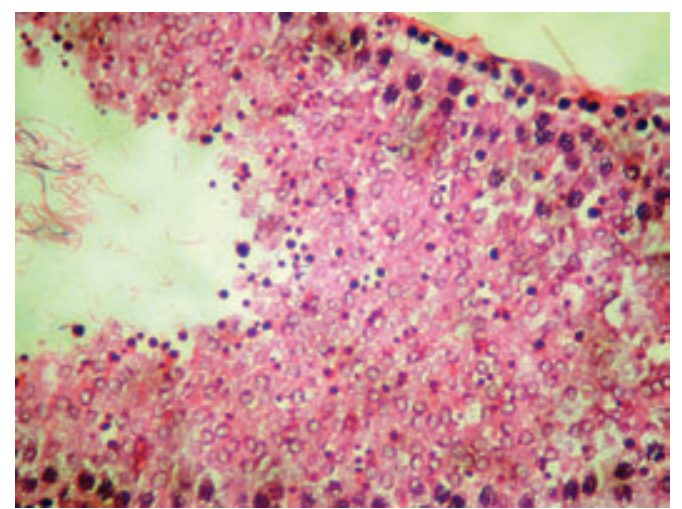

FIGURE 6 - Photomicrograph of compromised seminiferous tubules (G2: ischemia-reperfusion). Right testis, 400×. Structural damage to epithelium is evident, as well as remnants of sperm cell flagella.

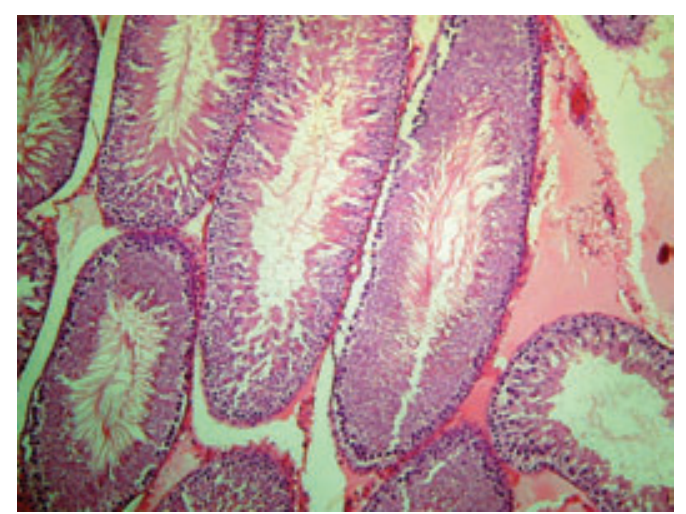

FIGURE 7 - Photomicrograph of seminiferous tubules (G3: ischemiareperfusion + propofol). Left testis. Note tubules with normal sperm cell flagella and well-organized germ cells. Partial necrosis and structural damage of the germinal epithelium are evident.

No histological changes related to structural damage were found in G1.

In G2 (Table 2), structural damage to seminiferous tubules was significantly greater in the testis ipsilateral to cord torsion $(p<0.05)$ than in the contralateral testis. 
TABLE 2 - Structural changes in seminiferous tubules, as percentage of abnormality after testicular torsion in rats not treated with propofol.

\section{Group 2 (ischemia-reperfusion)}

\begin{tabular}{ccc}
\hline Animal & $\begin{array}{r}\text { Abnormal seminiferous tubules (\%) } \\
\text { Left testis }\end{array}$ & \begin{tabular}{c} 
Right testis \\
\hline 1
\end{tabular} \\
2 & 58 & 63 \\
3 & 61 & 46 \\
4 & 90 & 56 \\
5 & 98 & 57 \\
6 & 100 & 83 \\
7 & 87 & 87 \\
8 & 100 & 82 \\
9 & 100 & 41 \\
10 & 81 & 93 \\
Mean & 86.6 & 70 \\
SD & 17.525854 & 67.8 \\
$P$ & & 17.9925911 \\
\hline
\end{tabular}

*Student's $t$-test

In G3 (Table 3), structural damage did not differ significantly between left and right testes.
TABLE 3 - Structural changes in seminiferous tubules, as percentage of abnormality after testicular torsion in rats treated with propofol.

\section{Group 3 (ischemia-reperfusion + propofol)}

\begin{tabular}{ccc}
\hline Animal & $\begin{array}{c}\text { Abnormal seminiferous tubules (\%) } \\
\text { Left testis }\end{array}$ & \begin{tabular}{c} 
Right testis \\
\hline 1
\end{tabular} $5^{29}$ \\
2 & 63 & 49 \\
3 & 34 & 60 \\
4 & 39 & 51 \\
5 & 63 & 22 \\
6 & 56 & 44 \\
7 & 61 & 40 \\
8 & 89 & 52 \\
9 & 78 & 43 \\
10 & 31 & 49 \\
\hline Mean & 57.3 & 45.1 \\
SD & 18.5175592 & 10.0934522 \\
$P$ & & 0.06866305 \\
\hline
\end{tabular}

*Student's t-test

Table 4 shows that protection against structural damage to seminiferous tubules was significantly higher in G3 (propofoltreated animals) than in G2 (no propofol).

TABLE 4 - Structural changes to seminiferous tubules, as percentage of abnormality after testicular torsion in rats (group $2 \times$ group 3 ) .

\begin{tabular}{lccccc} 
& $\begin{array}{c}\text { Group2 } \\
\text { (ischemia- } \\
\text { reperfusion) }\end{array}$ & $\begin{array}{c}\text { Group3 } \\
\text { (ischemia- } \\
\text { reperfusion }+ \\
\text { propofol) }\end{array}$ & \\
\hline Mean & SD & Mean & SD & $p^{*}$ \\
\hline Left testis & 86.6 & 17.5 & 57.3 & 18.5 & 0.000486 \\
Right testis & 67.8 & 18 & 45.1 & 10.1 & 0.009851 \\
\hline
\end{tabular}

*Student's $t$-test 


\section{Discussion}

Testicular torsion is a frequent occurrence in emergency care services, requiring emergency surgery. Duration and degree of spermatic cord torsion are the two most important factors determining the extent of testicular damage.

A number of substances have been investigated for their potential to protect testicular tissues against the effects of ischemiareperfusion. In the present study, the antioxidant propofol was employed to prevent testicular damage by eliminating reactive oxygen and nitrogen species and inhibiting lipid peroxidation ${ }^{10,11}$.

Harrison et al. ${ }^{12}$, examining the relationship between duration of testicular ischemia-reperfusion and tissue damage in rats, found that testes subjected to $720^{\circ}$ torsion for $1 \mathrm{~h}$ or $2 \mathrm{~h}$ lost their function, with no improvement 60 days later, despite reestablished blood flow. In the present study, ischemia-reperfusion was maintained for $1 \mathrm{~h}$, in line with other studies investigating this phenomenon in rat testes ${ }^{13,14}$.

The literature highlights the positive effects of propofol in preventing tissue damage for such cases. Yagmurdur et al. ${ }^{15}$ demonstrated that propofol can prevent testicular damage by eliminating reactive oxygen and nitrogen species and inhibiting lipid peroxidation. The present results corroborate these benefits of propofol. Tissue damage was observed in both testes, with greater injury to the organ ipsilateral to cord torsion. In both testes, propofol attenuated the occurrence of tissue damage, indicating the beneficial effects of this compound for testicular ischemiareperfusion.

The histological classification proposed by Cosentino et al. ${ }^{9}$ now widely adopted for evaluating testicular tissue injury secondary to testicular ischemia-reperfusion, was used in the present study.

Unsal et al. ${ }^{16}$ performed $720^{\circ}$ testicular torsion with ischemic time of $2 \mathrm{~h}$ and $25 \mathrm{mg} / \mathrm{kg} / \mathrm{h}$ of propofol. Histological examination revealed well-structured tubules with spaces between cells, in addition to some areas of hemorrhage. Similar results were found in the present study, despite shorter ischemic time (1h) and propofol administration at $20 \mathrm{mg} / \mathrm{kg} / \mathrm{h}$.

Good results were also obtained by Avlan et al. ${ }^{17}$, whose study involved $720^{\circ}$ torsion and ischemic time of $4 \mathrm{~h}$, administration of selenium, and histological evaluation based on Cosentino et al. ${ }^{9}$.

Silva et al. ${ }^{18}$ also performed spermatic cord torsion at $720^{\circ}$ for $1 \mathrm{~h}$, administering allopurinol intraperitoneally $45 \mathrm{~min}$ after torsion. Allopurinol, however, failed to protect testicular tissues against the effects of ischemia-reperfusion, in contrast to the results obtained by the present study using propofol.

Erol et al. ${ }^{19}$, investigating spermatic cord torsion in rats, used the intraperitoneal route to inject the anesthetic. Torsion to $720^{\circ}$ was maintained for $1 \mathrm{~h}$. Vardenafil was administered to protect against ischemia-reperfusion, reducing the occurrence of necrosis.

Yurtçu et al. ${ }^{20}$ performed $720^{\circ}$ torsion of spermatic cord for $6 \mathrm{~h}$ and administered melatonin before detorsion. Histological evaluation, conducted according to Cosentino et al. ${ }^{9}$, revealed a good level of protection.

Based on the results of this study and those in the literature, it can be inferred that administration of propofol at the dose investigated conferred protection to testes of rats against ischemia-reperfusion.

\section{Conclusion}

Propofol conferred tissue protection against the effects of testicular ischemia-reperfusion in rats.

\section{References}

1. Ryan PC, Whelan CA, Gaffney EF, Fitzpatrick JM. The effect of unilateral experimental testicular torsion in prepubertal rats. $\mathrm{Br} \mathrm{J}$ Urol. 1988;62:359-66.

2. Currie BG, Kern IB, Hagan BE. Torsion of the testis. Med J. 1989;151:568-74

3. Skoglund RW, McRoberts JW, Ragde H. Torsion of the spermatic cord: a review of the literature and an analysis of 70 new cases. J Urol. 1970;104:604-7.

4. Cosentino MJ, Nishida M, Rabinowitz R, Abraham TK, Cockett ATK. Histopathology of prepubertal rat testes subjected to various durations of spermatic cord torsion. J Androl. 1986;7:23-31.

5. Baker LA, Turner TT. Leydig cell function after experimental testicular torsion despite loss of spermatogenesis. J Androl. 1995;16:12-7.

6. Reilly PM, Schiller HJ, Bulkley GB. Pharmacologic approach to tissue injury mediated by free radicals and other reactive oxygen metabolites. Am J Surg. 1991;161:488-500.

7. Prillaman HM, Turner TT. Rescue of testicular function after acute experimental torsion. J Urol. 1997;157:340-5.

8. Hamaguchi S, Mishio M, Okuda Y, Kitajina T. Propofol and lipid peroxidation. Can J Anaesth. 2000;47:1025-30.

9. Cosentino MJ, Nishida M, Rabinowitz R, Cockett ATK. Histological changes occurring in the contralateral testis of prepubertal rats subjected to various durations of unilateral spermatic cord torsion. J Urol. 1985;133:906-11.

10. Yagmurdur H, Ayyildiz A, Karaguzel E, Ogus E, Surer H, Caydere M, Nuhoglu B, Germiyanoglu C. The preventive effects of thiopental and propofol on testicular ischemia-reperfusion injury. Acta Anaesthesiol Scand. 2006;50(10):1238-43.

11. Santos CHM, Gomes OM, Pontes JCDV, Miiji LNO, Higa EI. Uso do propofol (2,6 diisopropilfenol) como inibidor da lesão tecidual na isquemia e reperfusão mesentérica: estudo experimental em ratos. Acta Cir Bras. 2003;18(4):347-54.

12. Harrison RG, Lewis-Jones D.I, Marval MJM, Connolly RC. Mechanism of damage to the contralateral testis in rats with an 
ischaemic testis. Lancet. 1981;2:723-5.

13. Ozturk BH, Buyukbayram H, Ozdemir E, Ketani A, Gurel A, Onem A, Diyarbakir SO, Zonguldak T. The effects of nitric oxide on the expression of cell adhesion molecules (ICAM-1, UEA-1, and Tenascin) in rats with unilateral testicular torsion. J Pediatr Surg. 2003;38(11):1621-7.

14. Steinberg E, Tijoe DY. Spermatogenesis in rat testis after experimental ischaemia. Fertil Steril. 1969;20:639-49.

15. Yagmurdur H, Ayyildiz A, Karaguzel E, Akgul T, Ustun H, Germiyanoglu C. Propofol reduces nitric oxide-induced apoptosis in testicular ischemia-reperfusion injury by downregulating the expression of inducible nitric oxide synthase. Acta Anaesthesiol Scand. 2008;52(3):350-7.

16. Unsal A, Devrim E, Guven C, Erogiu M, Durak I, Bozoklu A, Balbay MD. Propofol attenuates reperfusion injury after testicular torsion and detorsion. World J Urol. 2004;22(6):461-5.

17. Avlan D, Erdougan K, Çimen B, DüsmezAD, Cinel I, Aksöyek S. The protective effect of selenium on ipsilateral and contralateral testes in testicular reperfusion injury. Pediatr Surg Int. 2005;21(4):274-8.

18. Silva ACMB, Ortiz V, Silva RA, Tognini JR. Efeito do alopurinol sobre a morfologia do testículo do rato submetido a isquemia, pela torção do cordão espermático seguida de reperfusão. Acta Cir Bras. 2005;20(6):468-71.

19. Erol B, Tokgoz H, Hanci V, Bektas S, Akduman B, Yencilek F, Mungan G, Mungam A. Vardenafil reduces testicular damage following ischemia/reperfusion injury in rats. Kaohsiung J Med Sci. 2009;25(7):374-80.

20. Yurtçu M, Abasiyanik A, Avunduk MC, Muhtaroglu S. Effects of melatonin on spermatogenesis and testicular ischemia-reperfusion injury after unilateral testicular torsion-detorsion. J Pediatr Surg. 2008;43:1873-8.

\section{Correspondence:}

Carlos Henrique Marques dos Santos

Rua Aluisio de Azevedo, 606

79004-050 Campo Grande - MS Brasil

Received: September 5, 2011

Review: November 7, 2011

Accepted: December 12, 2011

Conflict of interest: none

Financial source: none

${ }^{1}$ Research performed at Surgery Department, School of Medicine, Federal University of Mato Grosso do Sul (UFMS), Campo Grande-MS, Brazil. 